\title{
Interactive roles of monovalent and divalent cations in pathogenesis of hypertension caused by alcohol
}

\author{
F A A ADENIYI \\ From the Department of Chemical Pathology, College of Medicine, University of Ibadan, Ibadan, Nigeria
}

SUMMARY Subjects whose daily alcohol intake varied from less than $22 \mathrm{~g}$ to over $88 \mathrm{~g}$ were studied. They differed in their mean systolic and diastolic blood pressures compared with those of controls who were teetotallers. The association between alcohol consumption and blood pressure was independent of age. Ex-alcohol users who were much older than current alcohol users had lower systolic and diastolic blood pressures. The association of body mass index with sustained raised blood pressure was apparent. When body mass index was eliminated as a variable there was an appreciable residual effect on mean arterial pressure.

Alcohol users and controls did not differ in mean plasma sodium concentration. Red blood cell intracellular sodium concentration, however, was higher in beer drinkers than in controls. On the other hand, red blood cell intracellular concentration of magnesium in beer drinkers was decreased. It is suggested that definite interactions between sodium, magnesium, and calcium ions may have some vital roles in the sustained rise in blood pressure in alcohol users.

Coronary heart diseases are common in Nigeria. ${ }^{1-3}$ Although it is now well established that there are a multiplicity of risk factors for development of coronary heart disease such as hypertension, hyperlipidaemia, obesity, physical inactivity and stressful living, ${ }^{4}$ the interactive roles of dietary monovalent and divalent metals have not been emphasised until relatively recently. ${ }^{5}$ Several reports from other countries have suggested a relation between alcohol consumption, dietary sodium and potassium, and essential hypertension. ${ }^{6-8}$ There are still conflicting data, however, about the roles of dietary sodium and potassium as major factors in the pathogenesis of essential hypertension. ${ }^{8-9}$

Chronic alcoholism has long been known to be associated with a net body loss of magnesium, evidenced by low serum and myocardial tissue magnesium. ${ }^{10}$ In addition, $40-80 \%$ of chronic alcoholics develop high blood pressure. ${ }^{11-12}$ In Nigeria lager beer is a favourite alcoholic beverage. The raw materials used in beer production in Nigeria-barley and yeast-are imported mainly from Europe, but the brewing of the beer is done entirely locally. The quality of the finished product, however, is said to conform to international standards for lager beers. The alcoholic content of Nigerian beer ranges from $3 \cdot 0-3.5 \%$, but no data are available about the inorganic content. In a previous study in this laboratory,

Accepted for publication 21 May 1986 however, it was observed that lager beer contains almost five times as much the sodium content of locat drinking water $(1.75(0.48)(\mathrm{mEq} / \mathrm{l}) \quad v \quad 0.38(0.13)$ $\mathrm{mmol} / \mathrm{l})(\mathrm{mEq} / \mathrm{l}){ }^{13}$

In view of the widespread consumption of lager beers in Nigeria due to the increase in disposable income of urban wage earners, it was thought valid to investigate the interactive roles of some inorganic metals in the development of high blood pressure in beer drinkers.

\section{Material and methods}

Adiposity in all subjects selected for this study was assessed using Quetelet's body mass index weight $(\mathrm{kg}) / \mathrm{height}^{2}(\mathrm{~m})$ : systolic and diastolic (phase $\mathrm{V}$ of the Korotkov sounds) blood pressures were measured using a standard mercury sphygmomanometer with regular cuffs. Readings were taken in the seated position after 20 minutes of rest. Mean arterial pressure (MAP) was calculated by the addition of diastolic pressure and one third of the pulse pressure (diastolic blood pressure plus one third (systolic blood pressure-diastolic blood pressure)). Subjects were classified as having raised blood pressure if they had a diastolic blood pressure of greater than $90 \mathrm{~mm} \mathrm{Hg}$ or a systolic blood pressure of greater than $150 \mathrm{~mm} \mathrm{Hg}$, or both.

After all subjects had rested for a further 10 minutes, to allow for haemodynamic equilibration, 10 
$\mathrm{ml}$ venous blood samples were drawn from an antecubital vein using sterile, non-toxic pyrogen free plastic syringes. The blood was carefully emptied into heparinised tubes, gently mixed, and then centrifuged. The plasma was separated into plain plastic tubes and the buffy coat retained for some other studies. The fresh cells were next washed using the procedure that has been standardised by Lijnen and others. ${ }^{14}$ The cells were washed three times with ice cold choline chloride $(140 \mathrm{mM})$. The cells were then haemolysed with double distilled water, and intracellular sodium and magnesium were measured by flame photometry (Elvi, Milano). Plasma sodium and magnesium were also measured by flame photometry using the same instrument.

The significance of differences was assessed using the student's $t$ test for unpaired observations and the $\chi^{2}$ test and correlation coefficient and regression tests for association.

The selected subjects for the study, all men, fell into three categories:

\section{CATEGORY 1}

Eighty eight beer drinkers comprising 39 blood donors, 32 members of Ibadan University community, and 17 men who were attending the general outpatients' clinic of a government hospital for routine medical examinations were included in this category.

Table 1 Graded alcohol consumption of healthy male beer drinkers

\begin{tabular}{ll}
\hline No of subjects & Alcohol consumption (g/day) \\
\hline 14 & $11-22$ \\
16 & $22-44$ \\
35 & $44-66$ \\
13 & $66-88$ \\
10 & 88 and above \\
\hline
\end{tabular}

The mean age of the men was $32 \cdot 2$ (SD 6.1, range 21-46) years. They were selected using the following criteria:

(i) Every volunteer had to have at least a one year history of continuous alcohol (lager beer) consumption.

(ii) No volunteer was intoxicated at the time of blood collection.

(iii) The last beer was taken less than 24 hours before blood collection.

(iv) There was a history of at least seven days of daily beer consumption before blood collection.

(v) There was no clinical evidence of either overhydration or dehydration.

(vi) No volunteer had a medical history of cardiovascular, renal, hepatic, or any other metabolic disease.

(vii) No volunteer was receiving any form of medication.

Five groups of alcohol consumers were investigated (table 1). In Nigeria lager beer is sold in bottles each with a fluid capacity of $6.2 \mathrm{~m} / \mathrm{dl}$. One litre of Nigerian beer therefore contains $35.5 \mathrm{~g}$ of alcohol and 1.75 mmol (mEq/l) of sodium. ${ }^{13}$

The mean body mass index for this group of volunteers was 20.3 (SD 2.5, range 16.3-27.8). Their mean systolic and diastolic blood pressures were 154 (SD 23, range 110-190) $\mathrm{mm} \mathrm{Hg}$ and 92 (SD 12, range 70-110) $\mathrm{mm} \mathrm{Hg}$, respectively (table 2 ).

\section{CATEGORY 2}

The second group of volunteers comprised 20 ex-beer drinkers. They were selected from the University of Ibadan staff community. The mean period of abstinence of these subjects was $8 \cdot 1(2 \cdot 3)$ range 5-12 years. Twelve used to be heavy drinkers ( $88 \mathrm{~g}$ alcohol/day) and had stopped drinking on medical advice. The

Table 2 Mean (SD) ages, body mass indexes, blood pressures, plasma and red blood cell intracellular sodium and magnesium concentrations in beer drinkers, ex-beer drinkers, and teetotallers

\begin{tabular}{|c|c|c|c|c|c|c|c|c|c|}
\hline & \multirow[b]{2}{*}{$\begin{array}{l}\text { No of } \\
\text { subjects }\end{array}$} & \multirow[b]{2}{*}{$\begin{array}{l}\text { Age } \\
\text { (years) }\end{array}$} & \multirow[b]{2}{*}{$\begin{array}{l}\text { Body mass } \\
\text { index }\end{array}$} & \multirow{2}{*}{$\begin{array}{l}\text { Systolic } \\
\text { blood } \\
\text { pressure } \\
(\mathrm{mm} \mathrm{Hg})\end{array}$} & \multirow{2}{*}{$\begin{array}{l}\text { Diastolic } \\
\text { blood } \\
\text { pressure } \\
(\mathrm{mm} \mathrm{Hg})\end{array}$} & \multicolumn{2}{|l|}{ Plasma } & \multicolumn{2}{|l|}{ Erythrocytes } \\
\hline & & & & & & $\begin{array}{l}\text { Sodium } \\
(\mathrm{mmol} / \mathrm{l})\end{array}$ & $\begin{array}{l}\text { Magnesium } \\
(\mathrm{mmol} / \mathrm{l})\end{array}$ & $\begin{array}{l}\text { Sodium } \\
\text { (mmol/l cells) }\end{array}$ & $\begin{array}{l}\text { Magnesium } \\
\text { (mmol/l cells) }\end{array}$ \\
\hline $\begin{array}{l}\text { Beer drinkers } \\
\text { Ex-beer drinkers } \\
\text { Teetotallers }\end{array}$ & $\begin{array}{l}88 \\
22 \\
92\end{array}$ & $\begin{array}{l}32 \cdot 2(6 \cdot 1)^{\mathrm{a}} \\
39 \cdot 1(4 \cdot 0)^{\mathrm{b}} \\
34.0(5 \cdot 7)\end{array}$ & $\begin{array}{l}20.3(2.5)^{c} \\
19.2(3.8) \\
18.9(3.0)\end{array}$ & $\begin{array}{l}154(23)^{d} \\
136(32) \\
132(20)\end{array}$ & $\begin{array}{l}92(12)^{e} \\
80(13) \\
81(11)\end{array}$ & $\begin{array}{l}134(7)^{f} \\
135(7) \\
138(6)\end{array}$ & $\begin{array}{l}0.3(0.2)^{0} \\
0.9(0.3) \\
0.8(0.3)\end{array}$ & $\begin{array}{l}8 \cdot 4(1 \cdot 3) \\
7.9(1 \cdot 1)^{h} \\
6 \cdot 5(1 \cdot 5)\end{array}$ & $\begin{array}{l}2 \cdot 1(0.6)^{i} \\
3.4(0.8) \\
3 \cdot 2(0.8)\end{array}$ \\
\hline
\end{tabular}

a Compared with that of teetotallers, value not significantly different; $p>0 \cdot 10$.

b Compared with that of beer-drinkers and teetotallers, value significantly increased; $\mathbf{p}<0.001$.

c Compared with those of teetotallers, values significantly higher; $0.01<\mathrm{p}<0.005$.

d Compared with those of teetotallers, values significantly higher; $p<0.001$; Compared with that of ex-beer drinkers, value significantly higher; $\mathrm{p}<0.005$.

e Compared with that of teetotallers and ex-beer drinkers, values significantly higher; $\mathbf{p}<0.001$.

$f$ Compared with that of teetotallers and ex-beer drinkers, values not significantly different; $p>0.70$.

g Compared with that of teetotallers and ex-beer drinkers, values significantly lower; $p<0 \cdot 001$. higher; $\mathrm{p}<0.0125$.

i Compared with that of ex-beer drinkers and teetotallers, values significantly lower; $p<0.005$. 


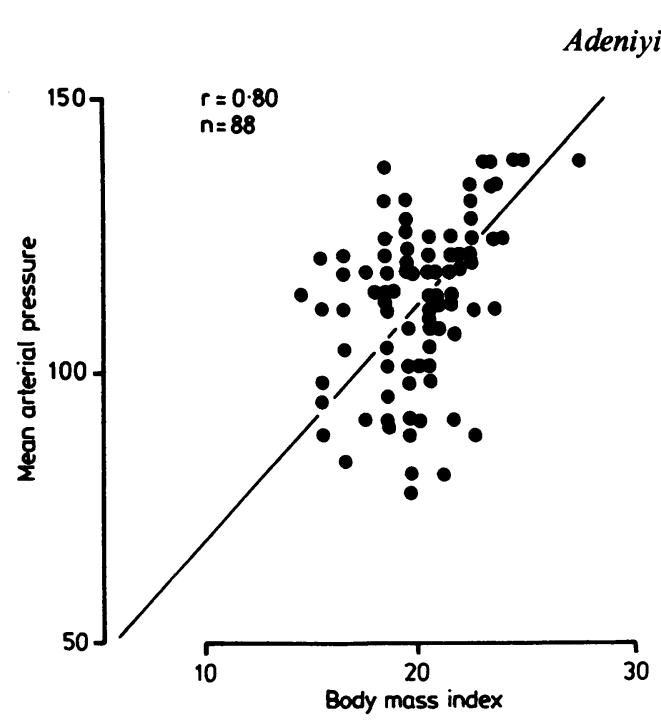

remaining eight subjects used to drink lightly $(22 \mathrm{~g}$ alcohol/day) and had stopped drinking on their own initiative. The mean age of this group of subjects was 39.1 (4.0) range $30-49$ years and their mean body mass index was $19.2(3.8)$ range $14.0-22.5$ years. The mean values for systolic and diastolic blood pressures were 136 (32) range $105-180 \mathrm{~mm} \mathrm{Hg}$ and 80 (13) range $65-100 \mathrm{~mm} \mathrm{Hg}$.

\section{CATEGORY 3}

In the third group were 92 healthy men who were total abstainers. They comprised 18 blood donors, 11 members of Ibadan University staff clinic, and 63 muslims who were at an epidemiological clinic of a government hospital to obtain the mandatory inoculations preparatory to pilgrimage trips to the Middle East. Their average age was $34.0(5 \cdot 7)$ range $20-48$ years and their average body mass index was 18.9 (3.0) range $14 \cdot 0-25 \cdot 2$. Mean systolic and diastolic blood pressures were $132(20)$ range $100-180 \mathrm{~mm} \mathrm{Hg}$ and 81 (11) range $60-110 \mathrm{~mm} \mathrm{Hg}$, respectively.

\section{Results}

GENERAL CHARACTERISTICS OF THE SUBJECTS The beer drinkers and the teetotallers who used neither alcohol nor tobacco did not differ in their mean age but they differed in their mean body mass index (table 2). Although the ex-beer drinkers were older, they did not have a higher mean body mass index than the two other groups of subjects (table 2). Systolic and diastolic blood pressures were higher in beer drinkers than in ex-beer drinkers and in teetotallers (table 2). There was also a significant degree of positive correlation between body mass index and mean arterial pressure in beer drinkers (figure). When 20 teetotallers who had a comparable mean body mass index with 14 subjects who were consuming 11-22 g alcohol per day (the least amount of alcohol consumption), however, were compared, using the $\chi^{2}$ test, there was a significant association between alcohol consumption and raised mean arterial pressure (table 3). Mean arterial pressure was also higher in subjects consuming $66 \mathrm{~g}$ of alcohol/day than in those who were consuming less than $22 \mathrm{~g}$ of alcohol/day. Both groups of subjects also had comparable body mass indices (table 4).

Figure Correlation between body mass index and mean arterial pressure in beer drinkers.

Table 2 shows the extracellular and red blood cell intracellular concentrations of sodium and magnesium in all three categories of subjects investigated. The mean plasma sodium did not differ greatly in all the subjects. Plasma magnesium, however, was lower in beer drinkers than in teetotallers and ex-beer drinkers. The mean red blood cell intracellular sodium concentration was higher in beer drinkers than in teetotallers, but there was no change when compared with the intracellular sodium in ex-beer drinkers. The red blood cell intracellular magnesium concentration was also lower in beer drinkers than in teetotallers and ex-beer drinkers.

Table 4 Mean arterial blood pressure in subjects consuming different quantities of alcohol

\begin{tabular}{lll}
\hline & Body mass index & Mean arterial pressure \\
\hline $11-22 \mathrm{~g} / \mathrm{per}$ day & $19.6(4 \cdot 1)$ & $98 \cdot 3(13.4)$ \\
$66 \mathrm{~g} / \mathrm{per}$ day & $19.4(4 \cdot 0)$ & $114(16 \cdot 6)$ \\
$\mathrm{p}$ value & $>0.70$ & $<0.001$ \\
\hline
\end{tabular}

All values are means ( $\pm 1 \mathrm{SD})$.

Table 3 Association between raised mean arterial pressure and lager beer consumption

\begin{tabular}{llllll}
\hline & & $\begin{array}{l}\text { No with raised } \\
\text { mean arterial } \\
\text { pressure }\end{array}$ & $\begin{array}{l}\text { No with normal } \\
\text { mean arterial } \\
\text { pressure }\end{array}$ & $\chi^{2}$ test & $p$ value \\
\hline $\begin{array}{l}\text { Beer drinkers (11-22 g alcohol/day) } \\
\text { Teetotallers }\end{array}$ & $\begin{array}{l}19.6(4.1) \\
19.2(4.3)\end{array}$ & 8 & 6 & 5.15 & $0.02<\mathrm{p}<0.05$ \\
\hline
\end{tabular}

*Values are means \pm 1SD.

Mean arterial pressure $=$ diastolic $B P+\frac{1}{3}$ (pulse pressure). 


\section{Discussion}

Many studies have reported the correlation between alcohol consumption and blood pressure independent of the effects of both age and weight. ${ }^{15-17}$ The extent of the influence of these factors on the prevalence of hypertension is not clear, and the true mechanism of hypertension caused by alcohol is also presently unknown. In this study consumers of alcohol and teetotallers did not differ in their mean age but they did differ in their mean systolic and diastolic blood pressures. This suggests that age is not likely to be an important contributory factor in the development of hypertension, as has been reported by various groups. This suggestion is further corroborated by the finding of appreciably lower systolic and diastolic blood pressures in ex-beer drinkers who are much older than current alcohol users. There seems to be an association between body mass index and alcohol consumption, evidenced by a higher mean body mass index in beer drinkers compared with that of teetotallers. There was also a high degree of positive correlation between body mass index and increased mean arterial pressure. When the effect of body mass index was eliminated as a variable, however, it was again clear that both alcohol consumption on its own and the relative quantity of ingested alcohol have direct associations with increased mean arterial pressure. There is substantive evidence to show that either alcohol alone or other factors in the composition of lager beers are directly responsible for increased blood pressures in alcohol consumers.

Among the probable mechanisms that have been suggested for the sustained high blood pressure in alcohol users are increased sympathetic activity, ${ }^{18}$ Cushing's syndrome, induced by alcohol ${ }^{19}$ and activation of the renin-angiotensin system. ${ }^{20}$ None of these listed mechanisms, however, has been unequivocally established in most alcohol consumers. Indeed, Cushing's syndrome induced by alcohol with increased plasma cortisol concentration is comparatively rare. Alcohol has also not been generally shown to ensure the hyperactivity of the renin-angiotensinaldosterone system.

The hypomagnesemia, the increased intracellular concentration of sodium, and the decreased intracellular concentration of magnesium that have been established in the course of this study in beer drinkers have not been previously reported in this field. Apart from the universal causative effect of salt in the pathogenesis of essential hypertension in man, it seems that the increased sodium content, aside from the alcohol effect, in locally brewed Nigerian lager beers may be part of the explanation for the increased blood pressure that has been observed in this group of alcohol users. It has been established in a previous study that the locally brewed Nigerian lager beer contains five times as much as the sodium content of local drinking water. ${ }^{13}$

The hypomagnesemia and the decreased intracellular concentration of magnesium found in these beer drinkers may be related to the increase in the degree of basal tension of some small and large coronary arteries that has been observed after the experimental withdrawal of extracellular magnesium. ${ }^{21}$

A changed intracellular concentration of sodium has also been suggested as being able to change the transport of calcium ions by sodium-calcium exchange and thereby increasing the calcium concentration in the cells and tension in vascular smooth muscle. ${ }^{22}$ This mechanism may lead to the decreased intracellular concentration of magnesium in these alcohol consumers, resulting in increased basal tension and raised blood pressure.

Beer drinkers and ex-beer drinkers do not differ in their mean intracellular concentration of sodium (table 2). The increased intracellular magnesium concentration in ex-beer drinkers, however, may probably counteract the effect of ion accumulation via the sodium-calcium exchange mechanism. This may be part of the explanation for the normal blood pressure in this category of subjects in spite of the increased intracellular sodium concentration. Magnesium ions have been known to act as a regulatory cofactor in the cascade of events initiated by cell stimulation, which proceed through ion fluxes, enzymatic induction, energy dependent metabolic responses and return of the vascular cell to its basal state. ${ }^{23-26}$

The findings of this study suggest that definite interactions between sodium, magnesium, and calcium ions have some vital roles in the sustained increase of blood pressure seen in alcohol users.

I am grateful to Drs Oyelese and Akinwale for the facilities in their different clinics. I am also indebted to Dr OM Jeje and Mr S Ogedengbe, both of whom arranged for all the selected blood donors.

\section{References}

1 Lauckner JR, Rankin AM, Adi FC. Analysis of medical admissions to University College Hospital, Ibadan-1958. West Afr Med J 1961;10:3-32.

2 Parry EHO, Ikeme AC. Cardiovascular disease in Nigeria. Ibadan: University Press, 1966:68-76.

3 Carlisle R, Ogunlesi TO. Prospective study of adult cases presenting at the cardiac unit, University College Hospital, Ibadan 1968-69. Afr J Med Sci 1972;3:13-25.

4 Akinkugbe 0 . Cardiovascular disease in Africa. Proceedings of First all-Africa Cardiovascular Symposium, Ibadan, Nigeria, March 15-18, 1976. Ibadan: Ibadan University Press, 1976.

5 Postnov YV, Orlov SN. Cell membrane alteration as a source of primary hypertension. J Hypertension 1984;2:1-6.

6 D'Alonzo CA, Pell S. Cardiovascular disease among problem drinkers. J Occup Med 1968;10:344-50. 
7 Saunders JB, Beevers DG, Paton A. Factors influencing blood pressure in chronic alcoholics. Clin Sci 1979;57:295s-98s.

8 MacGregor GA. Dietary sodium and potassium intake and blood pressure. Lancet 1983;i:750-3.

9 Simpson FO. Salt and hypertension: current data, attitudes, and policies. J Cardiovasc Pharmacol 1984;6:S4-S9.

10 Flink EB, Omar M, Shane SR. Alcoholism, liver disease and magnesium. Magnesium Bulletin 1981;3:209-16.

11 Altura BM. Cardiovascular effects of alcohol and alcoholism. Fed Proc 1982;41:2437-76.

12 Friedman H, Geller HS. The effect of alcohol on the heart, skeletal, and smooth muscles. In: Lieber A, ed. Medical disorders of alcoholism. Philadelphia: WB Saunders, 1982.

13 Adeniyi FAA. Locally-brewed Nigerian lager beers and high BP. In: Hemphill DD, ed. Trace substances in environmental health $X X$. Columbia: University of Missouri. (in press).

14 Lijnen P, Fagard RH, Groeseneken DR, Staessen JA, Amery AK. Intracellular concentration and transmembrane fluxes of sodium and potassium in erythrocytes of White normal male subjects with and without a family history of hypertension. $J$ Hypertension 1984;2:25-30.

15 Klatsky AL, Friedman GD, Siegelaub MS, Gerard MJ. Alcohol consumption and blood pressure. New Engl J Med 1977; 296:1194-200.

16 Arkwright PD, Beilin LJ, Rouse I, Armstrong BK, Vandongen R. Effects of alcohol use and other aspects of life style on blood pressure levels and prevalence of hypertension in a working population. Circulation 1982;66:60-6.

17 Harburg E, Ozgaren F, Hawthorne VM, Scherk MA. Commu- nity norms of alcohol usage and blood pressure. Am J Pub Health 1980;70:813-20.

18 Saunders JB, Beevers DG, Paton A. Alcohol-induced hypertension. Lancet 1981;i:653-6.

19 Smalls AG, Kloppenborg PW, Njo KT, Knoben JM, Ruland CM. Alcohol-induced Cushing's syndrome. Br Med J 1976;ii: 1298.

20 Linkola J, Fyhrquist F, Ylikahri R. Renin, aldosterone and cortisol during ethanol intoxication and hangover. Acta Physiol Scand 1979;106:75-82.

21 Altura BM, Altura BT. Mg, $\mathrm{Na}$, and $\mathrm{K}$ interactions and coronary heart diseases. Magnesium 1982;1:241-65.

22 Blaustein MP. Sodium ions, calcium ions, blood pressure regulation, and hypertension: a reassessment and a hypothesis. $\mathrm{Am}$ J Physiol 1977;232:C165-C73.

23 Altura BM, Altura BT. Magnesium ions and contraction of vascular smooth muscles. Relationship to some vascular diseases. Fed Proc 1981:40:2672.

24 Shine II. Myocardial effects of magnesium. Am J Physiol 1979;237:H413.

25 Turlapaty PD, Altura BM. Extracellular magnesium ions control calcium exchange and content of vascular smooth muscle. Eur J Pharmacol 1978;54:421.

26 Ohhashi T, Azuma R. Contraction of arterial smooth muscle induced by magnesium ions. Am J Physiol 1982;242:C25.

Requests for reprints to: Dr FAA Adeniyi, Department of Chemical Pathology, College of Medicine, University of Ibadan, Ibadan, Nigeria. 